\title{
Nouns and academic interactions: a neglected feature of metadiscourse
}

\begin{abstract}
Metadiscourse has received considerable attention in recent years as a way of understanding the rhetorical negotiations involved in academic writing. But while a useful tool in revealing something of the dynamic interactions which underlie persuasive claim making, it has little to say about the role of nouns in this process. We address this gap by exploring the rhetorical functions of what we call metadiscursive nouns (such as fact, analysis, belief) and by mapping them onto a model of metadiscourse. The study examines "metadiscursive noun + postnominal clause" patterns, one of the most frequent structures containing such nouns, in a corpus of 120 research articles across six disciplines. Developing a rhetorically-based classification and exploring the interactive and interactional use of metadiscursive nouns, we show that they are another key element of metadiscourse, offering writers a way of organizing discourse into a cohesive flow of information and of constructing a stance towards it. These interactions are further shown to realize the epistemological assumptions and rhetorical practices of particular disciplines.
\end{abstract}

\section{Keywords}

metadiscursive nouns, metadiscourse, academic writing, persuasion, interaction 


\section{Nouns and academic interactions: a neglected feature of metadiscourse}

\section{Introduction}

The suasive nature of academic writing is now well established. Rather than simply the inscription of meticulously observed and recorded social or natural phenomena, we have come to see academic texts as artefacts of fact construction: as sites where authors rhetorically shape their interpretations to the expectations of their readers (Bazerman, 1988; AUTHOR, 2004). All reporting occurs in a disciplinary context and interpretations depend on what the mind allows the eye to see. Such shaping thus privileges particular interpretations and recognises certain community preferences of argument, so that knowledge depends on the ways that scientists present their claims. Thus academic papers are essentially conversations between members of academic communities who have some agreement on the ground rules for negotiating what counts as plausible. Persuasion is grounded in the conventional textual practices for producing agreement and is most clearly found at particular junctures of authorial intrusion where writers feel the need to justify decisions and engage their readers. Among the array of linguistic features examined to describe such junctures are those which comprise metadiscourse, a catch-all term to refer to "discourse about discourse" (Crismore, 1989; AUTHOR, 2005).

An example of metadiscourse is "according to" in (1) below. It is inserted as an "evidential marker" (AUTHOR, 2005) which denotes the source of information to guide the reader's interpretation, in this case, by helping to make the current discourse more obviously relevant to the information presented earlier:

(1) According to this paradigm, early stage species would spread predominantly via spore dispersal in young and disturbed habitats.

[Medicine]

We can, however, also see here an additional aspect of metadiscourse in the noun phrase "this paradigm". This serves to both remind readers of a previously mentioned 
analytical approach and offer the writer's assessment of that approach. It thus reveals the writer's decision to engage with the reader at this point by a) assisting comprehension through linking parts of the text cohesively and b) conveying a stance towards what is being discussed.

'Paradigm' is, in fact, just one of a range of abstract nouns found to play an important role in marking cohesion in academic writing (Charles, 2003, 2007; Flowerdew \& Forest, 2015; Francis, 1994; AUTHOR, 2015). They have not, however, figured before in the metadiscourse literature. We set out here to correct this oversight and attempt to map what we call metadiscourse nouns onto AUTHOR's (2005) metadiscourse model, showing how these nouns promote textual interactions between writers and readers in academic writing.

\section{Models of metadiscourse}

Metadiscourse is a concept used to describe the ways writers organise their texts to help readers interpret, evaluate and react to the propositional content they supply. It is a term which has, however, been understood from two perspectives: a broad/integrative view and a narrow/non-integrative one (Ädel \& Mauranen, 2010). The broad approach, found in the work of Crismore (1989), AUTHOR (2005) and Vande Kopple (1985), for example, sees metadiscourse as the ways writers organise a coherent text and convey their attitudes to what is discussed in the text. The narrow approach, championed by Ädel (2006) and Mauranen (1993), on the other hand, talks of 'discourse reflexivity' and restricts its focus to the way discourse talks about the on-going discourse itself. We take an integrative position and see metadiscursive nouns as performing both textual and interpersonal functions within a text.

AUTHOR (2005) offers perhaps the most comprehensive and theoretically wellgrounded model of metadiscourse (Thompson, 2008). Building on the work of Vande Kopple (1985) and Crismore (1989), AUTHOR argues that metadiscourse is "the cover term for the self-reflective expressions used to negotiate interactional meanings in a text" (2005, p. 37). Interaction is understood here as the writer's intervention to anticipate the reader's posible reactions, objections and procesing needs. It has two elements: 1) an interactive dimension which concerns the writer's awareness of readers and the need to shape the text to their 
expectations and requirements and 2) an interactional dimension which addresses the ways writers step into their texts to comment on their message and involve readers. Table 1 shows the main resources of this model.

Table 1 Hyland's model of metadiscourse (Hyland, 2005, p. 49)

\begin{tabular}{|c|c|c|}
\hline Category & Function & Examples \\
\hline Interactive & $\begin{array}{l}\text { Help guide readers through the } \\
\text { text }\end{array}$ & Examples \\
\hline Transitions & $\begin{array}{l}\text { express relations between main } \\
\text { clauses }\end{array}$ & in addition; but; thus; and \\
\hline Frame markers & $\begin{array}{l}\text { refer to discourse acts, sequences } \\
\text { or stages }\end{array}$ & Finally; to conclude; my purpose is \\
\hline Endophoric markers & $\begin{array}{l}\text { refer to information in other parts } \\
\text { of the text }\end{array}$ & noted above; see Fig; in section 2 \\
\hline Evidentials & $\begin{array}{l}\text { refer to information from other } \\
\text { texts }\end{array}$ & according to $X ; Z$ states \\
\hline Code glosses & elaborate propositional meanings & $\begin{array}{l}\text { namely; e.g .; such as; in other } \\
\text { words }\end{array}$ \\
\hline Interactional & Involve readers in the text & Examples \\
\hline Hedges & $\begin{array}{l}\text { withhold commitment and open } \\
\text { dialogue }\end{array}$ & might; perhaps; possible; about \\
\hline Boosters & $\begin{array}{l}\text { emphasise certainty or close } \\
\text { dialogue }\end{array}$ & in fact; definitely; it is clear that \\
\hline Attitude markers & $\begin{array}{l}\text { express writer's attitude to } \\
\text { proposition }\end{array}$ & unfortunately; I agree; surprisingly \\
\hline Self mentions & explicit reference to author(s) & I; we; my; me; our \\
\hline $\begin{array}{l}\text { Engagement } \\
\text { markers }\end{array}$ & $\begin{array}{l}\text { explicitly build relationship with } \\
\text { reader }\end{array}$ & consider; note; you can see that \\
\hline
\end{tabular}

So writers use interactive devices to either weave chunks of information together (transitions, frame markers and endophoric markers) or provide elaboration on propositional content (code glosses and evidentials). In this way they serve to create the discoursal cohesion and logical coherence, shaping texts to what readers may find familiar, plausible and persuasive. Interactional functions allow authors to express their viewpoints (hedges, boosters, attitude markers and self-mentions) and rhetorically pull readers into the discourse 
(engagement markers). Thus for AUTHOR, metadiscourse refers to the evolving text and to the writer and imagined readers of that text; making explicit the ways writers organise their message, engage readers and signal their attitudes to their material and their audience.

Metadiscursive nouns are absent in AUTHOR's frequently cited wordlist of metadiscourse markers, however, neglecting the important interactive and interactional roles they play in discourse. We intend to remedy this oversight here, introducing metadicourse nouns in the next section and then mapping them onto this metadiscourse model.

\section{Metadiscursive nouns}

We define metadiscursive nouns as those which refer to the organisation of the discourse or the readers' understanding of it. They are a sub-set of abstract nouns and distinguished from them by their unspecific semantic meaning. While the meaning of an abstract noun is constant across contexts (e.g. society, democracy) metadiscursive nouns have both this constant meaning and a variable, pragmatic meaning which depends on contextual lexicalization. They assist writers to point to material somewhere in the current context and shape how the reader responds to that material. It is this which allows these nouns to function metadiscursively, enabling writers to organise cohesive discourse, express viewpoints on content and interact with readers as members of a particular community, as we illustrate in these examples:

(2) This is further supported by the observation that chromatin bridges are bound by Rad52 and trigger degradation of Sml1.

[Biology]

(3) A possibility is that participants may have been intrigued to hear a 71year-old retiree speak about social media, and such curiosity may have increased interest toward the event. [Marketing]

(4) The PID controller, as can be seen in Fig. 6, results in a significant overshoot at the transient state (without programmed acceleration). To remedy this drawback, preprogramming of acceleration and deceleration 
periods is required, whereas they are not needed with CCC, P, and ZPETC methods.

[Electrical engineering]

(5) It can be argued that this is a particularly strong incentive in the context of the Bathroom Formula.

[Applied linguistics]

(6) According to the traditional view, this is evidence of agency discretion since we can associate policy change with different types of managers.

[Sociology]

"Observation", "possibility", "drawback", "incentive" and "view" are metadiscursive nouns and their vagueness is remedied by immediate reference. Thus it is unclear what "observation" and "possibility" refer to in (2) and (3) until they are specified cataphorically in the subsequent complementing clauses, while "drawback" and "incentive" in (4) and (5) are specified anaphorically in the previous stretch of discourse. "View" in (6) is slightly different as it relies on readers summoning a referent from their background knowledge outside the current text.

Flowerdew and Forest $(2015$, p. 2) also note this complementary relationship between a metadiscursive noun and what Winter (1992, p. 153) calls a "lexical realisation". The realisation provides the necessary specifics for the metadiscursive noun while the metadiscursive noun indicates how the realisation is meant to be understood in relation to the surrounding discourse. In all cases the metadiscursive noun provides a link with additional information, whether inside or outside the text. This helps writers move ideas along cohesively and so assist readers to gain a better comprehension of the connected information. These examples also exhibit the four most frequent lexico-grammatical patterns in which metadiscursive nouns are used, that is, $N+$ post-nominal clause $;+$ be + complementing clause; Demonstrative $+N$; Demonstrative + be $+N$ respectively (Schmid, 2000).

We can then say that metadiscursive nouns belong to the so-called "non-technical" (Meyer, 1997) or "procedural" (Luzón Marco, 1999) category of vocabulary as they are "highly context-dependent items with very little lexical content" (Luzón Marco, 1999, p. 1). 
Thus words like fact, analysis and process are more like function words and require specification. For example, the metadiscursive noun "analysis" in (7) below points to the information that the writer has already mentioned (underlined) and connects it with the ongoing sentence, assisting readers to make better sense of these pieces of information.

(7) the same values of $Q$ could be obtained for small $\varepsilon 1, \varepsilon 2$ materials, and for large $\varepsilon 1, \varepsilon 2$ materials. This provides an alternative expression for polarizability. This analysis assumes the capillary occupies a uniform field, and as such, cannot be applied to any SRR with extended conductors formed from circular cross-section wire.

\section{[Electrical engineering]}

The same interactive work could equally be done by the single demonstrative pronoun "this", of course, indicating that "analysis" is not functioning as a lexical item with clear semantic meaning. It is, in fact, open to a range of interpretations which are only closed down by the underlined specification. Nation observes that such non-technical items are becoming more grammatical, metadiscourse-like and "delexicalised" as they "depend more for its meaning on what it does or refers to in the text than what it carries with it" (Nation, 2001, p. 212)

So, in this interactive dimension, metadiscursive nouns either refer backward, to "encapsulate" earlier material into the ongoing discourse, or forward to "prospect" forthcoming information (Sinclair, 1993). They work to signal the relationships between parts of the text and address the management of information flow. This interactive function reveals a writer's awareness of a participating audience and the ways the text must accommodate its probable knowledge, rhetorical expectations and processing abilities. The writer's purpose here is "to shape and constrain a text to meet the needs of particular readers, setting out arguments so that they will recover the writer's preferred interpretations and goals" (AUTHOR, 2005, p. 49).

In addition to these interative, cohesive-type functions, AUTHOR (2015) and Charles $(2003,2007)$ have also gone on to explore the stance-making functions of these nouns. Here, 
metadisursive nouns work to convey a writer's authorial perspective on the content which the noun refers to. For example, "possibility" is used in sentence (3) as an alternative to, say, "phenomenon" or "fact" to label the subsequent proposition in a particular way as uncertain information rather than established actuality. Similarly, the writer in example (4) chose "drawback" to offer a negative evaluation of the PID controller described in prior sentences. Example (6) also reminds us how metadiscursive nouns can diretly address the reader, acknowledging their knowledge base and engaging them as discourse participants. In the interactional dimension, then, the writer's goal is "to make his or her views explicit and to involve readers by allowing them to respond to the unfolding text" (AUTHOR, 2005, p. 49). This is the writer's projection of community and exhibits the ways he or she conveys judgments, aligns with readers and responds to an imagined dialogue with them.

Clearly, the grammar is important here and syntactic patterns such as metadiscursive nouns + be + complementing clause allow speakers to introduce their attitude towards something "in a highly subtle way" (Schmid, 2000, pp. 310-312). We therefore dispute the idea suggested by Flowerdew (2015, pp. 29-30) such nouns constitute a single grammatical unit which can be easily substituted by alternatives "such as 'my hypothesis is that', 'my conclusion is that', 'my claim is that', or 'my promise is that"'. By embedding the noun as topic/given information, the writer suggests that its meaning can be taken for granted (Schmid, 2000).

Metadiscourse nouns thus set up writer-reader interactions in texts in both interactional and interactive dimensions. Interactive features emphasise the 'reader-friendly' aspects of written text: "the primary direction of the interaction is from reader to writer" (Thompson and Thetela 1995 , p. 104) as the writer predicts and responds to the reader's needs. The interactional element is where the writer decides "to bring their management of the unfolding of the text to the surface and to engage themselves and the readers explicitly in the process" (Thompson, 2001, p. 61). We will show that metadiscursive noun performs these two functions simultaneously when used in the " $\mathrm{N}+$ post-nominal clause" pattern, which is the 
focus of our study ${ }^{1}$. The noun is specified in the post-nominal content clause (Schmid, 2000; Downing \& Locke, 2006), during which they interactively refer forward to the content of the clause and interactionally label the stance that writers take towards this content.

These types of noun have been found to be very frequent in academic discourse (Charles, 2003, 2007; Flowerdew \& Forest, 2015; Gardner \& Davies, 2013) and so have attracted considerable attention, albeit under a range of different names. For Halliday and Hasan (1976) they are general nouns, for Ivanič (1991) carrier nouns, for Francis (1986) anaphoric nouns, for Flowerdew and Forest (2015) signaling nouns and for Schmid (2000) they are shell nouns. As many of these labels suggest, however, authors have largely been concerned with the discourse-organizing, interactive functions of these nouns (see BenitezCastro \& Thompson, 2015, for a critical review of the literature). With the exception of Charles $(2003,2007)$ and AUTHOR (2015), their interactional dimension has been almost entirely unexplored. We remedy this in the following sections, attempting a characterisation which recognises both, beginning with a description of the study.

\section{Study design, corpus and analysis}

In this study we illustrate the metadiscourse functions of these nouns by focusing on the most frequent lexico-grammatical pattern in which they occur: metadiscursive noun + post-nominal clause (Hunston \& Francis, 1999; Schmid, 2000). The productivity of this pattern lies in the fact that it both facilitates cataphoric linkage (interactive function) and the expression of the writer's stance (interactional function), although Benitez-Castro \& Thompson (2015) comment on the paucity of studies into the cataphoric use of these nouns. Focusing on this pattern also gives us a way to examine how these nouns function in the immediate within-clause context, since previous studies mainly explore the across-clause discourse-organizing functions of these nouns.

\footnotetext{
${ }^{1}$ When occurring in other patterns they sometimes have exophoric referrence, engaging readers in the interactional domain by asking them to summon a referent from their background knowledge, and this is not considered interactive cohesion. In other patterns they therefore perform interactional roles only.
} 
In this pattern, a metadiscursive noun takes a nominal complement either in the form of a that clause (8), to-infinitive clause (9), of-prepositional clause (10) or preposition-plus-wh clause (11). In each case the complement lexically specifies the metadiscursive noun by semantic equivalence:

(8) The first study targeted several brand communities under the assumption that participants in these communities are highly involved consumers and likely to have relatively close ties to brands.

[Marketing]

(9) These data led us to hypothesize that the apparently limited effects of MRP1/2 and RBP16 knockdown on mitochondrial RNA metabolism might be, at least in part, due to their abilities to perform some redundant functions in RNA editing and/or stability. [Biology]

(10) Criticisms of genre-based teaching include the potential danger of reifying the power structures in which genres are embedded.

[Applied Linguistics]

(11) An alternative example of how an SRR could be perturbed with a microfluidic capillary is shown in Fig. $2 . \quad$ [Electrical Engineering]

Thus the metadiscursive noun in this structure refers cataphorically to the propositional information provided in the post-nominal clause while the complement information specifies the meaning of the metadiscursive noun. "Assumption" in (8), for example, previews the proposition in its complement "participants in these communities are highly involved consumers and likely to have relatively close ties to brands" while also denoting the value the writer attributes to that idea.

The study draws on a 1.2 million word corpus of 120 research articles, 20 from each of six disciplines (electrical engineering, medicine, cell biology, applied linguistics, marketing and sociology). These disciplines span the spectrum of academic practice from the hard physical sciences to the more rhetorical humanities and social sciences, with two articles randomly selected from ten international journals in each field. The corpus was part of speech tagged using Tree Tagger then searched for the $N$ that, $N$ to-infinitive, $N$ of-preposition and 
preposition-plus-wh structures on the basis of syntactic information through regular expression query, using the concordance software AntConc (Anthony, 2014).

We further conducted a manual reading of concordance lines to improve the accuracy of the parsing and ensure all Noun post-nominal clauses had been identified. This also allowed us to consider tricky cases, such as "the evidence that cytFBPase could not be removed during immunoprecipitation". In this case, the post-nominal clause does not specify the content of what the evidence is but what the evidence proves. We decided, however, to follow Schmid (2000)'s practice of including such cases as "at the time that the prospective payment system was introduced". Although strictly grammatically speaking a relative clause with an adverbial gap, the post-nominal clause semantically specifies the "time", and "time" denotes how the author defines the piece of complement information.

In order to better understand what stance choices writers make in the interactional use of metadiscursive nouns, we created a functional categorization scheme through careful analysis of concordance lines and used this to code all the metadiscursive nouns using MAXQDAplus (2012). The frequency of the metadiscursive nouns in different categories and of different post-nominal clausal patterns were counted and comparisons were made across different disciplines and among different complement patterns. Both authors then independently analysed a sample of nouns in the corpus to ensure we were counting the same things in the same way to facilitate replication by others (95\% agreement).

\section{A Categorization of Metadiscursive nouns}

After numerous independently conducted sweeps through the corpus, we produced the model presented in Table 2 . This shows that metadiscursive nouns are functionally used to express how academic writers mark entities, describe attributes of entities and discuss the relations between entities. 
Table 2 Functional classification of metadiscursive nouns

\begin{tabular}{|c|c|c|}
\hline Entity & description & examples \\
\hline text & concrete metatext & report, paper, extract \\
\hline event & $\begin{array}{l}\text { events, processes, and } \\
\text { evidential cases }\end{array}$ & change, process, observation \\
\hline discourse & $\begin{array}{l}\text { verbal propositions and } \\
\text { speech acts }\end{array}$ & argument, claim, conclusion \\
\hline cognition & cognitive beliefs and attitudes & decision, idea, belief, doubt \\
\hline Attribute & description & examples \\
\hline quality & $\begin{array}{l}\text { traits that are admired or } \\
\text { criticised, valued or } \\
\text { depreciated }\end{array}$ & advantage, difficulty, value \\
\hline manner & $\begin{array}{l}\text { circumstances of actions } \\
\text { and state of affairs }\end{array}$ & time, method, way, extent \\
\hline status & $\begin{array}{l}\text { epistemic, deontic and } \\
\text { dynamic modality }\end{array}$ & $\begin{array}{l}\text { ability, capacity, possibility, } \\
\text { potential }\end{array}$ \\
\hline Relation & description & examples \\
\hline $\begin{array}{l}\text { cause-effect, } \\
\text { difference, etc. }\end{array}$ & $\begin{array}{l}\text { cause-effect, difference, } \\
\text { relevance }\end{array}$ & reason, result, difference \\
\hline
\end{tabular}

Nouns which characterise entities do so by either conveying writers' judgement of texts, events, discourses or aspects of cognition. Nouns representing texts refer to metatext, or concrete instances of text, so that examples such as report, paper and extract are typical. Event nouns refer to either occurences of actions and processes or mention of evidential cases, with examples such as change, process, attempt and observation being frequently used. Discourse nouns describe verbal propositions and speech acts, such as argument, claim and conclusion while Cognition nouns concern beliefs, attitudes and elements of mental reasoning, such as decision, idea, assumption and doubt.

Nouns relating to attributes concern writers' evaluations of the quality, status and formation of entities. Thus those pertaining to quality assess whether something is admired or criticised, valued or depreciated, with assessments falling on a scale of plus or minus (e.g. good-bad and important-unimportant), typically involving nouns such as advantage, difficulty and danger. Nouns relating to manner describe the circumstances and formation of actions 
and states of affairs. Examples such as time, method, way and extent depict either their dimensions in place and time, the way in which they are carried out or the frequency with which they occur. Metadiscursive nouns which concern status indicate the author's judgments of epistemic, deontic and dynamic modality (Palmer, 2001). Epistemic modality concerns possibility and certainty such as likelihood and truth; deontic modality relates to obligation and necessity such as need and obligation; dynamic modality describes ability, opportunity and tendency such as ability, capacity, potential and tendency.

Finally in our categorization, metadiscursive nouns are also used to encode how a writer understands the connection or relationship to information in a proposition, conveying relations such as reason, result and difference.

The model brings into focus how authors can use nouns to encode their subject matter, research processes, analyses and evaluations, all of which are central characteristics of academic work (Martin, 1976). It highlights how authors select metadiscourse nouns to orientate to different aspects of their research. For example, cognition nouns orient to writers' judgement of a proposition as a belief or attitude, while those in the status groups express an orientation towards the attributes of an entity. Thus we see that belief in (12) is functioning as a cognition rather than status noun as it does not concern the author's assessments of possiblity but how he characterises an attitude:

(12) This denial might arise from a genuine belief that the dead are powerless.

[Philosophy]

Similarly, a strictly semantic interpretation might classify choice in (13) as indicating the authors decion-making and so performing a cognitive role when considered out of context, rather than referring to the author's assessmnts of possibility. Thus an examination is needed, going beyond the immediate concordance lines of each noun, to look for the specifying content and identify what the writer seeks to express by each noun. 
(13) Whilst this might, at first sight, appear to include more than some within ANT would allow, it points to the choice of including the political, in a revised sense, within the very duality of the socio-natural commodity.

[Sociology]

The model, therefore, offers us a way to categorise the different stances that writers take up in their texts: describing how they define the information in the complement, what epistemic perspective they have and the kinds of affective attitudes they are taking towards the information. We believe this functional approach corrects an overemphasis on semantic interpretations found in other models (e.g. Schmid, 2000; Flowerdew \& Forest, 2015), which classfiy affect-laden nouns in strictly definitional terms.

Our more functional view suggests instead that each instance of a metadiscursive noun should be examined in its lexico-grammatical context rather than classifying it by semantic meaning alone. For one thing, this allows us to differentiate between epistemic judgments of status and assertions of actualities, a distinction which is often problematic for previous classifications. For example, Flowerdew and Forest's (2015) six category model includes three groups called facts (e.g. results), modal facts (e.g. possibility), and circumstantial facts (e.g. way). It is not entirely clear from this, however, how actual items are can be reliably distinguished in practice. The noun fact itself is always put into the facts group, presumably in recognition of its objective characterisation of an actual, cast-iron verifiable, state of affairs although it is frequently used to express the author's epistemic certainty. It seems to us, for example, that the authors are taking very different stances in these two statements:

(14) These subjects too learned less readily than controls in spite of the fact that the postulated 'interfering' response should actually have proved facilitatory in this case.

[Applied linguistics]

(15) we decided to determine a threshold of tHcy based on the fact that low CBS and low PON1 activities are atherogenic. 
In (14) the author is presenting a clear assertion of what he sees to be the truth of a finding, claiming that something actually happened while in (15) the author is simply offering a description of medical evidence. The use of "in spite of" in (14) signals that "the fact that" marks a contrast with the background information in the main clause; it is an evaluative use of the phrase which presents an assessment of a finding as a taken-for-granted assumption. At the same time it boosts the new finding by underlining the contrast and so highlighting it as opposed to an alternative outcome. In (15), on the other hand, the writer is portraying what has been established in medical experiments rather than asserting its truth.

These are admitedly tricky issues in discourse analysis which have taxed better minds than ours (e.g. Lyons, 1977; Palmer, 2001) and anaysts will likely continue to struggle with them into the future. However, in resolving whether the fact that should be interpreted as indicating the author is representating reality or expresing a judgment of certainty, that is whether it concerns an event or an attribute in our terms, we follow Labov (1972: 381) in appealing to potential comparisons. For him (as for Thompson \& Hunston, 2000: 13) fact marks an evaluation when a reference in a statement is compared to or contrasted with background information or values as here:

(16) Swan's description of the teacher's role ignores the fact that TBLT can include a pre-task and post-task phase, where opportunities arise for the explicit teaching of language.

\section{[Applied linguistics]}

The verb ignore before the fact that clause here signals the author is contrasting "Swan's description of the teacher's role" and "TBLT can include a pre-task and post-task phase", thus suggesting an epistemic interpretation of the phrase. Fact here presents the writer's judgment of truth value status of an entity rather than an assertion of verifiable evidence, persuading us to categorise it in the status group.

Having discussed the model and its potential classificatory advantages, we now go on to look at the metadicoursive role of these nouns.

\section{The freqeuncy and functions of metadiscursive nouns}


We identified 2,245 occurrences of metadiscursive nouns in Noun post-nominal clauses in the corpus, an average of 19 cases per article. Metadiscursive nouns occurred significantly more often in soft than hard fields, as Table 3 shows, with 1,867 cases in applied linguistics, marketing and sociology, averaging 25.7 per 10,000 words, and 378 cases in electrical engineering, medicine and biology, averaging just 7.6 per 10,000 words (log Likelihood $=$ $50.45, p<0.001)$. In other words, some $83 \%$ of all metadiscursive nouns occur in the more discursive soft fields.

Table 3 Distribution of metadiscursive nouns by discipline (per 10,000 words)

\begin{tabular}{ccccccc}
\hline & $\begin{array}{c}\text { App } \\
\text { ling }\end{array}$ & Markt & Soc & $\begin{array}{c}\text { Elec } \\
\text { eng }\end{array}$ & Med & Bio \\
\hline $\begin{array}{c}\text { Metadiscursive } \\
\text { nouns }\end{array}$ & 715 & 593 & 559 & 102 & 142 & 134 \\
$(30.9)$ & $(23.5)$ & $(22.9)$ & $(7.5)$ & $(9.1)$ & $(6.4)$ \\
\hline
\end{tabular}

The relative absence of metadiscursive nouns in the natural sciences suggests a less discursive and overtly persuasive discourse. The sciences rely far more on the generally assumed validity of certain lab procedures and prior research findings to support new claims. Nouns tend to be more technical and discplinary specific, fully lexicalised within each field and with fixed meanings and no general purpose counterparts (Flowerdew \& Forest, 2015, p. 94). We turn next to expand on our discussion of interactive and interactional roles of metadiscursive nouns

\subsection{Interactive functions: cohesion and coherence}

The interactive function refers to the author's anticipation that the reader will need some textual assistance to navigate the text. The reason we find so many metadiscursive nouns performing interactive work in the soft fields is because scholars here are more inclined to step into their texts to explicitly organise their discourse and set up expectations for the reader of what is to come. The following examples show something of this authorial 
intervention to guide readers through the argument, informing them of the possibility, motivation and belief of referents that will become clear in the following clause.

(17) we cannot rule out the possibility that only those participants who felt especially comfortable defending a moral decoupling argument selected this strategy.

[Marketing]

(18) students reflected on their achievement of goals and evaluated their motivation to keep on improving their writing ability by setting new goals.

[Applied linguistics]

(19) these graves obscure the racial story of the land belonging exclusively to the Jewish people, represented by the belief that ancient remains will authenticate only the Israelis' narrative of history.

\section{[Sociology]}

The author here is actively engaging the reader, excercising agency by informing readers of "how information can be tracked in the text" (Dahl, 2004: 1820). This is particularly important as regards the discursive nature of the soft disciplines which are typically characterised as relatively "loosely-knit academic communities" (Becher \& Trowler, 2001: 33) with less clearly defined and agreed disciplinary problems than the sciences. Researchable problems are less precisely defined and there are diverse and varied audiences. It is likely, therefore, that "the criteria the audience will apply are not clear-cut and universal, nor is it certain what intellectual framework they will bring to the reading" (Bazerman, 1988, p. 34). Thus the use of metadiscursive nouns in the above examples help to establish a frame of reference and guide readers regarding the grounds for and interpretations of further claims.

The hard sciences, in contrast, tend to be more "convergent and tightly knit" "urban" fields (Becher \& Trowler, 2001) so research is conducted along more recognisable pathways with broadly accepted methds and paradigms. Research exchanges are conducted within reasonably agreed boundaries of knowledge and defined ways of seeing the world, where a more homogeneous audience is able to see implicit cohesion of texts by virtue of their "craft 
skills in the specialized discourse" and "tacit knowledge from their daily work" rather than explicitly marked lexical relations (Myers, 1991, p. 6).

In the interactive dimension, metadiscursive nouns also help to create logical coherence from discoursal cohesion, shaping texts to what readers will find most familiar, plausible and persuasive. If we look back to (19), for example, the author's belief sets up prospective reference to the information that follows in the post-nominal clause, creating a cohesive stretch of discourse. At the same time, the author is seeking to ensure that readers find this cohesive flow of information logical and coherent. According to Halliday and Matthiessen (2014), the "logico-semantic relation" (logical and coherence relations) across clauses typically is developed through projection and expansion. Projection refers to the representation of ideas, what is thought (20), and locutions, what is said (21).

(20) The idea that energy efficiency allows the dematerialization of growth enables Giddens to avoid extending his critique of 'productivism' (or what he calls in Politics the 'fetish of growth') to an endorsement of environmentalists' calls for a 'no-growth society'.

[Sociology]

(21) These findings support our argument that moral decoupling does not threaten one's moral self-regard because it does not involve implicitly forgiving immoral actions.

[Marketing]

In terms of expansion, one clause either "elaborates" on the meaning of another through specification or clarification (22), "enhances" the meaning of another by reference to manner, cause or condition (23), or "extends" the meaning of another by addition, replacement, or alternative (24).

(22) we decided to ... determine a threshold of tHcy based on the fact that low CBS and low PON1 activities are atherogenic.

[Medicine]

(23) The structure modifies the electric field distribution and the channel potential in a way that beyond saturation, any additional variation in the drain to source voltage is absorbed under metal gate M2.

[Electrical engineering] 
(24) following an assessment, agreement is generally preferred to disagreement, with the exception of when an individual makes a negative assessment of themselves, such as 'I'm so useless', when disagreement is preferred.

[Applied linguistics]

Notions of projetion and expansion are useful to understanding the functioning of metadiscursive nouns because they help us to see the operation of authorial decision-making. It allows us to interpret (19) above, for example, "the belief that ancient remains will authenticate only the Israelis' narrative of history", as a case of projection, conveying an idea, and to undestand this choice as rhetorical since the writer could have chosen expansion (by using a metadiscursive noun such as $f a c t$ ). In this case it may have seemed more effective to the writer to present the information as a "figure of sensing" rather than a "figure of being" (Halliday \& Matthiessen, 1999, pp. 210-212). This projection of ideas also helps to explain why belief is classified as cognition rather than epistemic status in our categorisation.

Our functional categorisation can also suggest how metadiscursive nouns help formulate the logical and coherence relations with the referent that follows in the postnominal clause. For instance, discourse and cognition nouns are cases of projection, event nouns are indicative of expansion by elaboration, and the nouns in the manner group are expanded in the enhancement in the referent content. Table 4 summarises the distribution of projection and expansion found in the texts of different disciplines, with a rough mapping of relations between metadiscursive nouns and their content clauses. As we can see, both projection and expansion are used substantially more by writers in the soft sciences, indicating the greater investmemt such writers need to make in establishing rhetorical connections. The most significant differences lie in the projection of cognitive beliefs and propositional elaboration $(L L=19.06, p<0.001 ; L L=26.15, p<0.001)$.

Table 4 Coherence relations across disciplines (per 10,000 words) 


\begin{tabular}{c|c|cccccc}
\hline $\begin{array}{c}\text { Logico- } \\
\text { coherence } \\
\text { relation }\end{array}$ & $\begin{array}{c}\text { Functional } \\
\text { category }\end{array}$ & $\begin{array}{c}\text { App } \\
\text { ling }\end{array}$ & Markt & Soc & $\begin{array}{c}\text { Elec } \\
\text { eng }\end{array}$ & Med & Bio \\
\hline Projection & discourse & 1.9 & 1.2 & 1.6 & 0.0 & 0.4 & 0.2 \\
locution & 9.3 & $\mathbf{8 . 5}$ & $\mathbf{7 . 7}$ & $\mathbf{1 . 0}$ & $\mathbf{1 . 8}$ & $\mathbf{1 . 4}$ \\
idea & cognition & 7.4 & 7.3 & 6.1 & 1.0 & 1.4 & 1.2 \\
\hline Expansion & & $\mathbf{2 2 . 1}$ & $\mathbf{1 5 . 0}$ & $\mathbf{1 5 . 2}$ & $\mathbf{6 . 6}$ & $\mathbf{7 . 2}$ & $\mathbf{5 . 2}$ \\
elaboration & event, status, & 16.2 & 11.8 & 8.5 & 4.2 & 4.4 & 4.0 \\
extension & relation & 0.7 & 0.5 & 0.2 & 0.4 & 0.5 & 0.1 \\
enhancement & manner & 5.2 & 2.7 & 6.5 & 2.0 & 2.3 & 1.1 \\
\hline
\end{tabular}

The projection of ideas is more frequent in the humanities and social sciences as explicit interpretation, speculation and complexity are more commonly accepted as legitimate routes to understanding (AUTHOR, 2004). The machinery of knowledge-making largely lies in theoretical reasoning and "codified beliefs" (Bazerman, 1988, p. 126), which values the representation of beliefs and perceptual reasoning. These extracts give some flavour of this:

(25) Theoretical work (e.g., Engers and McManus, 2007, Ettinger, 2003 and Goeree et al., 2005) has investigated the properties of different formats of charity auctions under the assumption that bidders care about the charity's revenue.

[Marketing]

(26) Shared category membership builds trust through previously held beliefs about how members of the category will behave (Tajfel and Turner, 1986). [Sociology]

Because the social sciences deal with issues more subject to contextual and human caprice than those studied in the hard sciences, authors frequently add a "descriptive gloss" (Halliday \& Matthiessen, 2014, p. 464) to their accounts. As the examples below show, this propositional elaboration may either exemplify the argumentative grounds of the discussion (27), clarify interpretative variation (28) or specify an alternative possibility of events (29). 
(27) Thus, we provide another example of how the social processes responsible for crime control and crime itself are intertwined.

[Sociology]

(28) following an assessment, agreement is generally preferred to disagreement, with the exception of when an individual makes a negative assessment of themselves, such as 'I'm so useless', when disagreement is preferred.

(29) For example, it can be used to represent Fournier (1998) consumer brand relationship typology because it allows for the possibility that different configurations of relationship dimensions result in different consequences depending on how the relationship is formed. [Marketing]

Propositional elaboration thus helps to strengthen arguments and so make them more persuasive to a particular community of readers. In contrast to the predominance of propositional elaboration in the soft sciences, extension and enhancement are slightly more balanced across discplines (e.g. AUTHOR, 2007). Sociology and applied lingusitics employ propositional enhancement to a greater extent, perhaps reflecting a greater need to augment detail in argument, but clearly all fields have a need for precision.

In sum, metadiscursive nouns are part of an author's rhetorical armoury, allowing them to express judgements and assessments while recognizing readers' prior knowledge, possible comprehension difficulties and need for interpretative guidance. The writers' efforts to interweave ideas, organize propositional information and create a cohesive flow of information, moreover, is closely related to a discipline's argumentation practices and beliefs about knowledge. In their interactive role, then, metadiscursive nouns contribute to "a theory of experience in conventionally coherent ways" (AUTHOR, 2004, p. 116).

\subsection{Interactional dimension: stance and judgement}

The interactional dimension concerns the expression of viewpoints and engagement with readers. Here metadiscursive nouns indicating the writers' stance towards entities were 
the most common overall with the most frequent sub-category being that relating to cognition, describing the beliefs, attitudes and reasoning, comprising $25.5 \%$ of all metadiscursive nouns. Within the attribute category, authors' judgements most often concerned the status of referents, commenting on the certainty or necessity of something, with $21.6 \%$ of all metadiscursive nouns. Those expressing a stance by taking a view of the elements of manner attributes, showing the author's assessments of the contribution of these factors to the matter under study, comprise $17.8 \%$ of nouns. Nouns referring to texts and relations were used least of all. Table 5 summarizes these counts.

Table 5 Overall frequency of different types of metadiscursive nouns

\begin{tabular}{r|ccc}
\hline \multicolumn{1}{r}{ Categories } & $\begin{array}{c}\text { Total no. } \\
\text { of items }\end{array}$ & $\begin{array}{c}\text { Items per 10,000 } \\
\text { words }\end{array}$ & $\begin{array}{c}\text { \% of total } \\
\text { nouns }\end{array}$ \\
\hline Entity & $\mathbf{1 1 4 8}$ & $\mathbf{9 . 4}$ & $\mathbf{5 1 . 1}$ \\
\hline $\begin{array}{r}\text { texts } \\
\text { events }\end{array}$ & 20 & 0.2 & 0.9 \\
discourse & 432 & 3.5 & 19.2 \\
cognition & 123 & 1.0 & 5.5 \\
\hline Attribute & 573 & 4.7 & 25.5 \\
\hline quality & $\mathbf{1 0 6 3}$ & $\mathbf{8 . 7}$ & $\mathbf{4 7 . 3}$ \\
status & 178 & 1.4 & 7.9 \\
manner & 486 & 4.0 & 21.6 \\
\hline Relation & 399 & 3.3 & 17.8 \\
\hline Totals & $\mathbf{3 4}$ & $\mathbf{0 . 3}$ & $\mathbf{1 . 6}$ \\
\hline
\end{tabular}

These frequencies and types of metadiscursive nouns were not evenly distributed across disciplines, however, as can be seen in Table 6. When defining research entities, the soft fields generally use more cognition types while the hard sciences employ more event types, albeit at much lower frequencies. These different choices are not, of course, random but represent clear disciplinary preferences. Event nouns are closely related to real world activities, or empiricism, and cognition types to interpretive rationality, indicating different modes of knowing and sources of knowledge in the disciplines (Chafe \& Nichols, 1986). 
Thus the soft knowledge domains rely to a much greater extent on cognitive interpretation and the construction of theoretical modes of understanding than the hard sciences. In contrast, the hard sciences create knowledge based on empirical evidence and the creation of facts through experimentation and replication (e.g. Becher \& Trowler, 2001). The distribution of metadiscursive nouns thus not only indicates the different stances writers take towards arguments but also suggests something of the knowledge construction practices of their fields.

Table 6 Metadiscursive nouns across disciplines per 10, 000 words (\% of total)

\begin{tabular}{|c|c|c|c|c|c|c|}
\hline $\begin{array}{l}\text { per } 10,000 \\
(\% \text { of total })\end{array}$ & App ling & Markt & Soc & Elec eng & Med & Bio \\
\hline Entity & $\begin{array}{c}16.4 \\
(52.9) \\
\end{array}$ & $\begin{array}{c}12.6 \\
(53.6)\end{array}$ & $\begin{array}{c}12.1 \\
(52.8)\end{array}$ & $\begin{array}{c}2.7 \\
(35.5) \\
\end{array}$ & $\begin{array}{c}4.0 \\
(44.4)\end{array}$ & $\begin{array}{c}2.9 \\
(44.6)\end{array}$ \\
\hline \multirow{2}{*}{$\begin{array}{l}\text { texts } \\
\text { events }\end{array}$} & 0.2 & 0.2 & 0.2 & 0.0 & 0.3 & 0.0 \\
\hline & 6.9 & 3.9 & 4.2 & 1.7 & 1.9 & 1.6 \\
\hline \multirow{2}{*}{$\begin{array}{l}\text { discourse } \\
\text { cognition }\end{array}$} & 1.9 & 1.2 & 1.6 & 0.0 & 0.4 & 0.2 \\
\hline & 7.4 & 7.3 & 6.1 & 1.0 & 1.4 & 1.1 \\
\hline Attribute & $\begin{array}{c}14.3 \\
(46.1) \\
\end{array}$ & $\begin{array}{c}10.5 \\
(44.7) \\
\end{array}$ & $\begin{array}{c}10.2 \\
(44.5) \\
\end{array}$ & $\begin{array}{c}4.7 \\
(63.2) \\
\end{array}$ & $\begin{array}{c}5.0 \\
(\mathbf{5 5 . 6}) \\
\end{array}$ & $\begin{array}{c}3.6 \\
(55.4) \\
\end{array}$ \\
\hline \multirow{3}{*}{$\begin{array}{l}\text { quality } \\
\text { status } \\
\text { manner }\end{array}$} & 2.7 & 2.0 & 1.1 & 1.2 & 0.6 & 0.4 \\
\hline & 6.7 & 6.2 & 3.2 & 1.6 & 2.1 & 2.1 \\
\hline & 4.9 & 2.3 & 5.9 & 1.9 & 2.3 & 1.1 \\
\hline Relation & $\begin{array}{c}0.3 \\
(1.0)\end{array}$ & $\begin{array}{c}0.4 \\
(1.7)\end{array}$ & $\begin{array}{c}0.6 \\
(2.6)\end{array}$ & $\begin{array}{c}0.1 \\
(1.3)\end{array}$ & $\begin{array}{c}0.0 \\
(0.0)\end{array}$ & $\begin{array}{c}\mathbf{0 . 0} \\
(\mathbf{0 . 0})\end{array}$ \\
\hline Totals & $\begin{array}{c}31.0 \\
(100)\end{array}$ & $\begin{array}{c}23.5 \\
(100)\end{array}$ & $\begin{array}{c}22.9 \\
(100)\end{array}$ & $\begin{array}{c}7.5 \\
(100)\end{array}$ & $\begin{array}{c}9.0 \\
(100)\end{array}$ & $\begin{array}{c}6.5 \\
(100)\end{array}$ \\
\hline
\end{tabular}

The almost complete absence of discourse types of metadiscursive nouns in the sciences shows a reluctance to build claims through reference to the text or to the argument. We might also add here that compared with other soft knowledge fields, applied linguistics is much closer to the sciences in its preference for stance-taking which is oriented towards events, indicating a greater involvement in empirical and applied research than business and sociology. So we find observation and instance used repeatedly, as here: 
(30) The strong semantic link between L1 lexical forms and meaning is evidenced, for example, in the observation that forward translation is affected by semantic variables while backward translation remains unaffected by these semantic factors.

[Applied linguistics]

(31) There are many successful instances of showcasing Japanese cultural traditions in which English is drawn into...

[Applied linguistics]

In addition to using more metadiscursive nouns to define entities (as texts, events, discourse acts or beliefs), authors in the soft fields also make nearly three times more use of them to evaluate these entities, amounting to 11.6 compared with 4.3 per 10,000 words $(L L=$ $89.32, p<0.001)$. Once again, this supports previous research which indicates how authors in the humanities build knowledge through arguments which depend on personal interpretations and negotiations with readers (Bazerman, 1988; AUTHOR, 2004, 2005). The positions of these writers, for example, are unambiguously foregrounded by their choice of metadiscursive noun:

(32) In whole or in part the curtailment is perceived by the individual as reducing the risk that someone will be punished as a response to the activity.

[Sociology]

(33) Because moral decoupling does not involve condoning immoral acts, employing this strategy poses less danger of compromising one's moral standards.

[Marketing] (34) The misunderstandings I will consider have arisen for a number of reasons, but two in particular: misrepresentations of the theoretical rationale for TBLT and a failure to acknowledge the differences that exist among advocates of TBLT.

[Applied linguistics]

The distinctive stance-taking preferences of writers in different disciplines can also be seen from the most frequently used metadiscursive nouns. Table 7 shows the frequency rank of these nouns across disciplines in the corpus. 
Table 7 The ten most frequent metadiscursive nouns in each discipline by rank

\begin{tabular}{|c|c|c|c|c|c|}
\hline App ling & Marketing & Sociology & Elec eng & Medicine & Biology \\
\hline way & ability & way & fact & evidence & ability \\
need & decision & fact & ability & ability & evidence \\
fact & way & assumption & cost & paradigm & fact \\
attempt & intention & attempt & time & method & hypothesis \\
opportunity & likelihood & view & method & mechanism & model \\
process & willingness & idea & way & fact & attempt \\
context & evidence & evidence & possibility & hypothesis & finding \\
case & fact & process & attempt & possibility & idea \\
possibility & need & sense & period & attempt & inability \\
ability & opportunity & probability & assumption & effort & mechanism \\
\hline
\end{tabular}

Overall, the most frequent stance nouns in the corpus were way, fact, ability, capacity and evidence with most of the top ten occurring in manner and event categories. In terms of cognition stance nouns, idea, assumption and hypothesis are most common but decision, uniquely, only occurs in the top ten in marketing, comprising a massive $22.6 \%$ of all cognition types in that discipline. Business studies is a field governed by pragmatism and persuasive tropes that are oriented to options in the real world. Here, for example, authors attribute considerable power of agency to corporate decision-makers and so underpin the authority of marketing behaviours:

(35) Thus, a manufacturer's decision to distribute products through wholesalers and sales representatives with a well perceived image is crucial for a brand's success.

[Marketing]

(36) Large retailers such as Aldi, Tesco or Wal-Mart often have much more power than their suppliers, and their decision to carry a product or not can significantly affect a manufacturer's success.

[Marketing] 
There are a few other points to note about the nouns in Table 7. The high use of paradigm in medicine, for example, results from its use in a single paper, but the exclusive appearance of time and period + that clause in electrical engineering to depict the manner in which actions are taken is worth mentioning.

(37) This implies that there is a good chance the processing of the first record will be complete by the time that the second record is located, so that skip-sequential processing win provide benefits. [Electrical engineering]

(38) By considering machine depot, in each period that there is surplus capacity, idle machines can be removed from the cells and transferred to the machine depot.

[Electrical engineering]

The relationship of electrical engineering to a commercial world which employs its research in the service of industrial development and commercial reward ensures that the manner in which work is conducted is a key factor of argumentation. An orientation to the time taken to carry out work therefore figure heavily in the stance taking practices of authors.

In sum, writers can use metadiscursive nouns to construct a perspective on issues which their colleagues and peers can readily recognize and perhaps find effective. The sketch we have provided in this section has sought to address the neglect of this feature in the literature and to establish its importance in the expression of epistemological views and judgments.

\section{Conclusion}

The importance of metadiscourse in understanding the rhetorical and interpersonal effects of academic writing is now well established. But while the notion is a useful tool in revealing something of the dynamic interactions which underlie persuasive claim making, it has neglected the role which nouns can play in this process. Not only are they often ignored by academic writing teachers as being familiar 'non-technical' terms (Meyer, 1997), but they are typically overlooked in analyses. So Dahl (2004 p. 1813), for example, explicitly rejects them because "I feel that the verb represents a clearer expression of the author's presence in 
the text than, e.g., a nominal form: I/We argue gives me a stronger feeling of authorial presence than my/this argument".

While this may be true, we hope to have shown that what we have called metadiscursive nouns are a critical resource in academic interactions, offering writers a way of organizing discourse into a cohesive flow of logical and coherent information and of constructing a stance towards material. The frequency and ubiquity of this structure, we feel, testifies to its importance in creating arguments which allow authors to take ownership of their ideas while remaining sensitive to the disciplinary preferences and modes of knowing of their readers.

As a result of this importance, we believe that teachers might profitably seek to raise students' awareness of the interactive and interactional functions that metadiscursive nouns offer them. As McCarthy (1991, p. 76) comments on procedural vocabulary (which includes metadiscursive nouns), "if the words are seen as signals of the author's intent, then inability to understand them or misinterpretation of them could cause problems". Thus students who are unaware of these nouns may struggle to decode interactive connections in the text and to recognise the author's interactional position. Explicit instruction is therefore necessary to demonstrate the rhetorical functions of metadiscursive nouns, sensitizing learners to both interactive and interactional uses through sufficient illustrative examples and text replacement activities. Various tasks can then encourage students to identify these nouns in texts, how they are lexicalised in context and what stance writers express are expressing with them.

Finally, we hope to have shown not only that metadiscursive nouns are a valuable feature of the academic's rhetorical toolbox, but that these nouns themselves are a key element of metadiscourse itself. Out contribution, we believe, has been to both map the functions and distribution of these nouns across discplines, and to create a robust functional classification for them. The classification reveals how they can be understood as performing both interactive and interactional functions and hopefully encourages others to include metadusciurseive nouns in their research of academic writing. 


\section{References}

Ädel, A. (2006). Metadiscourse in L1 and L2 English. Amsterdam: John Benjamins.

Ädel, A., \& Mauranen, A. (2010). Metadiscourse: Diverse and divided perspectives. Nordic Journal of English Studies, 9(2), 1-11.

Anthony, L. (2014). AntConc (Version 3.4.3 w) [Computer Software]. Tokyo, Japan: Waseda University. Retrieved from http://www.antlab.sci.waseda.ac.jp/

Bazerman, C. (1988). Shaping Written Knowledge: The genre and activity of the experimental article in science. Madison: University of Wisconsin Press Madison.

Becher, T., \& Trowler, P. (2001). Academic Tribes and Territories: Intellectual enquiry and the culture of disciplines. Buckingham: Society for Research into Higher Education \& Open University Press.

Benitez-Castro, M.-A., \& Thompson, P. (2015). Shell-nounhood in academic discourse: A critical state-of-the-art review. International Journal of Corpus Linguistics, 20(3), $378-404$.

Chafe, W., \& Nichols, J. (1986). Evidentiality: The linguistic coding of epistemology. Orwood, NJ: Ablex Publishing.

Charles, M. (2003). 'This mystery...': a corpus-based study of the use of nouns to construct stance in theses from two contrasting disciplines. Journal of English for Academic Purposes, 2(4), 313-326.

Charles, M. (2007). Argument or evidence? Disciplinary variation in the use of the Noun that pattern in stance construction. English for Specific Purposes, 26(2), 203-218.

Crismore, A. (1989). Talking with Readers: Metadiscourse as rhetorical act. New York: Peter Lang.

Dahl, T. (2004). Textual metadiscourse in research articles: A marker of national culture or of academic discipline? Journal of Pragmatics, 36(10), 1807-1825.

Downing, A. \& Locke, P. (2006). English Grammar: A university course (2nd ed.). London: Routledge. 
Flowerdew, J. (2015). Revisiting metadiscourse: Conceptual and methodological issues concerning signalling nouns. Ibérica, (29), 15-34.

Flowerdew, J., \& Forest, R. W. (2015). Signalling Nouns in English: A corpus-based discourse approach. Cambridge: Cambridge University Press.

Francis, G. (1986). Anaphoric Nouns. Birmingham: English Language Research, University of Birmingham.

Francis, G. (1994). Labelling discourse: An aspect of nominal-group lexical cohesion. In M. Coulthard (Ed.), Advances in Written Text Analysis (pp. 83-101). London: Routledge.

Gardner, D., \& Davies, M. (2013). A new academic vocabulary list. Applied Linguistics, 35(3), 305-327.

Halliday, M. A. K., \& Hasan, R. (1976). Cohesion in English. London: Longman.

Halliday, M. A. K., \& Matthiessen, C. M. I. M. (1999). Construing Experience Through Meaning: A language-based approach to cognition. London: Continuum.

Halliday, M. A. K., \& Matthiessen, C. M. I. M. (2014). Halliday's Introduction to Functional Grammar (4th ed.). London: Taylor \& Francis.

Hunston, S., \& Francis, G. (2000). Pattern Grammar: A corpus-driven approach to the lexical grammar of English (Vol. 4). Amsterdam: John Benjamins.

Hyland, K. 2004. Disciplinary Discourses: Social Interactions in Academic Writing. University of Michigan Press.

Hyland, K. 2005. Metadiscourse: Exploring Interaction in Writing. Continuum.

Hyland, K. 2007. 'Applying a gloss: Exemplifying and reformulating in academic discourse,' Applied Linguistics 28: 266-85.

Ivanič, R. (1991). Nouns in search of a context: A study of nouns with both open-and closedsystem characteristics. International Review of Applied Linguistics in Language Teaching, 29(2), 93-114.

Labov, W. (1972). Language in the Inner City: Studies in the Black English vernacular. Pennsylvania: University of Pennsylvania Press. 
Luzón Marco, M. J. (1999). Procedural vocabulary: Lexical signalling of conceptual relations in discourse. Applied Linguistics, 20(1), 1-21.

Lyons, J. (1977). Semantics Vols 1 \& 2. Cambridge: Cambridge Univiersity Press.

Martin, A. V. (1976). Teaching academic vocabulary to foreign graduate students. TESOL Quarterly, 10(1), 91-97.

Mauranen, A. (1993). Cultural Differences in Academic Rhetoric: A textlinguistic study. Frankfurt: Peter Lang.

MAXQDAplus. (2012) (Version 11) [Computer software]. Berlin, Germany: VERBI GmbH.

McCarthy, M. (1991). Discourse Analysis for Language Teachers. Cambridge: Cambridge University Press.

Meyer, P. G. (1997). Coming to Know: Studies in the lexical semantics and pragmatics of academic English. Tübingen: Gunter Narr Verlag.

Myers, G. (1991). Lexical cohesion and specialized knowledge in science and popular science texts. Discourse Processes, 14(1), 1-26.

Nation, I. S. P. (2001). Learning Vocabulary in Another Language. Cambridge: Cambridge University Press.

Palmer, F. (2001). Mood and Modality. Cambridge: Cambridge University Press.

Schmid, H.-J. (2000). English Abstract Nouns as Conceptual Shells: From corpus to cognition (Vol. 34). Berlin: Walter de Gruyter.

Sinclair, J. M. (1993). 'Written discourse structure' in J. M. Sinclair, M. Hoey \& G. Fox (Eds.), Techniques of Description: Spoken and written discourse (pp. 6-31). New York: Routledge.

Thompson, G. (2001). Interaction in academic writing: Learning to argue with the reader. Applied Linguistics, 22(1), 58-78.

Thompson, G. (2008). Book Review: AUTHOR, Metadiscourse: Exploring interaction in writing. Language in Society, 37(1), 138-141. 
Thompson, G., \& Hunston, S. (2000). Evaluation: An introduction. In S. Hunston \& G. Thompson (Eds.), Evaluation in Text: Authorial stance and the construction of discourse (pp. 1-27). Oxford: Oxford University Press.

Thompson, G., \& Thetela, P. (1995). The sound of one hand clapping: The management of interaction in written discourse. TEXT, 15(1), 103-127.

Vande Kopple, W. J. (1985). Some exploratory discourse on metadiscourse. College Composition and Communication, 82-93.

Winter, E. O. (1977). A clause-relational approach to English texts: a study of some predictive lexical items in written discourse. Instructional Science, 6(1), 1-92.

Winter, E. O. (1992). The notion of unspecific versus specific as one way of analysing the information of a fund-raising letter. In W. C. Mann \& S. A. Thompson (Eds.), Discourse Description: Diverse linguistic analyses of a fund-raising text (pp. 131170). Amsterdam: John Benjamins. 